\title{
THE ROLE OF ENABLING TECHNOLOGIES IN TRANSFORMATIVE INNOVATION
}

\author{
Marion, Tucker; Friar, John \\ Northeastern University
}

\begin{abstract}
This study is an exploratory analysis of enabling technologies' influence on the trajectory of industry development using a co-evolutionary model of technology development. When combined, enabling technologies can create new technology-market industry cycles, resulting in transformative innovation. The research approach of this empirical study is to use both primary and secondary data to create a history of the robotics industry and to explore the pre and post changes in the industry from the inclusion of enabling technologies over multiple generations. We propose a new model for understanding the theoretical and practical study of technology development through the lens of enabling technologies and their development and maturity cycles.
\end{abstract}

Keywords: Technology, Market implications, Case study

Contact:

Marion, Tucker

Northeastern University

Entrepreneurship and Innovation

United States of America

t.marion@neu.edu

Cite this article: Marion, T., Friar, J. (2019) 'The Role of Enabling Technologies in Transformative Innovation', in Proceedings of the 22nd International Conference on Engineering Design (ICED19), Delft, The Netherlands, 5-8 August 2019. DOI:10.1017/dsi.2019.135 


\section{INTRODUCTION}

In the study of innovation, research over many decades has concentrated on the locus of innovation, and on how truly transformative changes result from the commercialization of new technologies. These new technologies may form new industries, or disrupt existing ones. From Schumpeter's work in the 1930's, to Utterback and Christensen, scholars have looked to develop models and frameworks to describe this phenomenon. Schumpeter (1942) discussed the concept of creative destruction of industries from within, which thereby create new industries. Abernathy and Utterback (1978) focused on industry dynamics and dominant designs. Utterback and Suarez (1993) looked at the role of incremental and radical technologies. Christensen (1997) focused on the role of new technologies, which while lower in initial performance, can ultimately displace entrenched technologies and transform industrial segments. Balachandra, Goldschmitt \& Friar (2004) discussed technology and market cycles, noting that true change comes from new ventures that develop a market dominant application within a new industry. What these models overlook is the important role that subordinate technologies play in the ultimate development of a transformative innovation.

In innovation, most technologies are systems composed of several technologies. Therefore, the system or master technologies rely on subordinate or supporting technologies for their further development. These supporting technologies become enabling technologies when they are combined to foster and create enhancements in the capabilities of the master, superior technology. An example is jet powered commercial aircraft. The De Havilland Comet and Boeing 707 were the first commercially available passenger jets brought to market in the 1950's. The enabling technologies of this transformative innovation include the turbojet engine itself, advances in metallurgy allowing light yet strong aluminum alloy airframes, turbo compressors for pressurized cabins, and reliable hydraulics for control surfaces. Although many studies have been done on how enabling technologies have enhanced other technologies, these studies are predominantly focused in the engineering literature (e.g. Baltes et al., 2013). Management studies that have looked at one technology's impact on another have mostly discussed technology-influenced industry convergence: on how two seemingly dissimilar product areas become substitutes for each other. Even in industry convergence, however, there have been few studies on industry dynamics (Stieglitz, 2003). Enabling technologies are different from converging technologies in that the respective industries remain distinct. Few studies in the innovation management literature have been done on how enabling technologies alter technology-market evolution and foster the creation of transformative innovations such as jet air travel, the smartphone, or long range electric vehicles. In this paper we focus on how enabling technologies influence the dynamics of industry evolution. Using a detailed case study, we illustrate our model using enabling technology development in the industrial robotics industry. Industrial robotics was chosen because they are complex system technologies with several enabling, subordinate technologies. In the next section, we review relevant literature and propose several research questions. This is followed by a description of our research methods and a discussion of our case study. Next, we discuss our results and propose an enabling technologies framework. We conclude with a section on managerial implications and thoughts on future research.

\section{LITERATURE REVIEW}

The study of dynamics of industry and technology evolution has a long and rich tradition in innovation management literature. There have been several models on the dynamics of industry development, such as punctuated equilibrium (Loch \& Huberman, 1999) and dominant designs (Abernathy \& Utterback, 1978), which analyze the development of technologies and industries. There are also models of market and industry development (Moore, 1991). Those two groups of models mainly focus on either technological or market changes. Research in both camps tend to agree that a new technology has a staged trajectory, and once technological or market uncertainties decline, a dominant technology will emerge (Kuhn, 1962; Dosi, 1982; Abernathy \& Clark, 1985). More recent studies have focused on the concept of cumulative knowledge building and evolution over time that leads to continuous improvement of technology and innovation (Gallini and Scotchmer, 2002; Murray and O'Mahony, 2007). This is contrasted by disturbances in technology trajectories which can alter technological paths by introducing a disruptive alternative (Christensen, 1997, 2010). 
Some recent studies have started to pay attention to coevolution of technologies and markets instead of evolution. Balachandra, Goldschmitt \& Friar (2004) proposed a double helix model that illustrated the coevolution pattern of technologies and markets. The model explains technology and market interactions over multiple generations in the process of industry evolution are governed by application and technology cycles. Another attempt explored the coevolution of design and technology (Schweisfurth, Tietze \& Herstatt, 2011). A third study created a model of the coevolution of technologies and categories during industry emergence (Suarez, Grodal \& Gotsopoulos, 2015). These studies, however, do not look at how enabling technologies influence the technology-market interaction. In this study, we will use coevolution theory rather than the evolution theory to analyze how enabling technologies can influence industry development.

\subsection{The importance of enabling technologies}

In looking at a number of emerging industries, we see that superior or master technological innovations are comprised of a subset of enabling technologies. In Table 1, we highlight five industries, ranging from commercially available genetic services (e.g. 23andme), commercial space flight (e.g. SpaceX), self-driving cars (e.g. Waymo), media content delivery (e.g. Netflix), and quantum computing (e.g. D-wave). In each case, enabling technologies combined to allow the formation of the master innovation. Each of these subordinate or enabling technologies have had their own cycle of market and technology coevolution, which can take decades to reach commercial viability.

Table 1. Industry verticals and associated enabling technologies

\begin{tabular}{|c|c|c|c|c|c|}
\hline & $\begin{array}{l}\text { Genetic } \\
\text { Testing }\end{array}$ & $\begin{array}{l}\text { Commercial } \\
\text { Spaceflight }\end{array}$ & $\begin{array}{c}\text { Self- } \\
\text { Driving } \\
\text { Cars }\end{array}$ & $\begin{array}{c}\text { Media } \\
\text { Content } \\
\text { Delivery }\end{array}$ & $\begin{array}{c}\text { Quantum } \\
\text { Computing }\end{array}$ \\
\hline Enabling Technology 1 & $\begin{array}{l}\text { Mapped } \\
\text { Genome }\end{array}$ & $3 \mathrm{D} \mathrm{CAD}$ & LIDAR & $\begin{array}{l}\text { High } \\
\text { Bandwidth } \\
\text { Cellular } \\
\text { Networks }\end{array}$ & $\begin{array}{l}\text { Theoretical } \\
\text { Physics }\end{array}$ \\
\hline Enabling Technology 2 & $\begin{array}{l}\text { Faster } \\
\text { Assay } \\
\text { Equipment }\end{array}$ & $\begin{array}{l}\text { Virtual } \\
\text { Prototyping } \\
\text { and Analysis }\end{array}$ & $\begin{array}{l}\text { Low- } \\
\text { Cost } \\
\text { Digital } \\
\text { Cameras }\end{array}$ & $\begin{array}{l}\text { Broadband } \\
\text { LAN Lines }\end{array}$ & $\begin{array}{l}\text { Fast } \\
\text { Simulations }\end{array}$ \\
\hline Enabling Technology 3 & $\begin{array}{l}\text { Data } \\
\text { Analytics }\end{array}$ & $\begin{array}{l}\text { Improved } \\
\text { Inertial } \\
\text { Guidance }\end{array}$ & $\begin{array}{l}\text { MEMS } \\
\text { Sensors }\end{array}$ & $\begin{array}{l}\text { Smartphones } \\
\text { and Tablets }\end{array}$ & $\begin{array}{l}\text { Data } \\
\text { Analytics }\end{array}$ \\
\hline Enabling Technology 4 & $\begin{array}{l}\text { Artificial } \\
\text { Intelligence }\end{array}$ & $\begin{array}{l}\text { Additive } \\
\text { Manufacturing }\end{array}$ & $\begin{array}{l}\text { Data } \\
\text { Analytics }\end{array}$ & $\begin{array}{l}\text { Cloud-Based } \\
\text { Storage }\end{array}$ & $\begin{array}{l}\text { Super } \\
\text { Conducting } \\
\text { Materials }\end{array}$ \\
\hline
\end{tabular}

An example of an individual enabling technology is 3D computer-aided-design (CAD), which plays a key role in new ventures such as SpaceX who use the powerful, low cost tools to design complex systems. Research in CAD began in the 1950's, but high levels of market penetration were not seen until the mid-to-late 1990's. Even then, CAD seats were expensive, and so were the computers used to run them. During the next decade, with the introduction of Solidworks, which could run on a PC or laptop, market penetration and access to capable software for relatively little cost transformed the digital design industry. Other competitors such as CATIA and PTC continued development of increasingly capable systems. This technology, combined with new ways to rapidly prototype and test, has allowed firms like Blue Origin and SpaceX to design, test, and develop new components and rockets in less time and for less cost than ever before. These technologies, when combined, have enabled these new ventures to begin to develop a new industry (i.e. commercial spaceflight). A framework for the enabling technology timeline is show in Figure 1. As the market and technology coevolve, the technologies move from high cost, specialized applications to lower cost, volume applications. It is then that each of these separate technologies are mature enough to combine for the master, transformative innovation. In the CAD example, moving from mini computers to laptops, and in 3D printing from expensive stereo lithography (SLA) machines to relatively low cost Makerbot and 
Objet machines, combine to alter how we design and develop new technology. In this example allowing smaller, less resource rich firms to compete with established firms (e.g. Boeing). While this is a process example, enabling component technologies follow the same path. In the self-driving car example described in Table 1, lower cost light detection and ranging (LIDAR), rugged and low cost digital cameras, micro-electrical-mechanical (MEMS) sensors, and data analytics have made the prospect of true autonomous vehicles a possibility.

\section{Technology Development Framework}

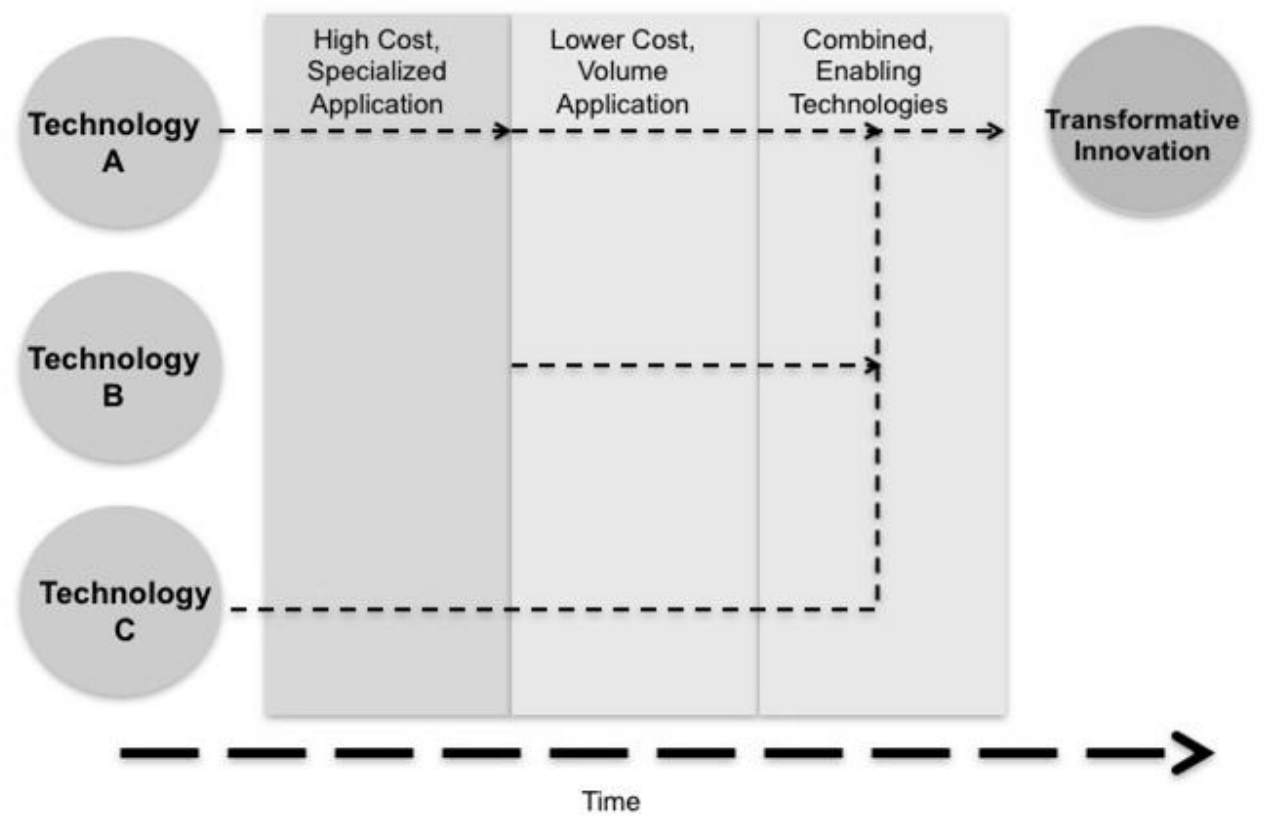

Figure 1. Enabling technology development framework

\subsection{Research questions}

Using the Balachandra et al. (2004) model of technology and market coevolution, we propose three research questions. The model discusses macro changes in industry development in that technology advances will eventually create a new cycle of industry development. The new cycle is characterized by new applications and new customers using the technology. With the start of a new cycle, there is industry turbulence with the existing leaders being unseated by new competitors. The first research proposition is:

RQ1: Enabling technologies initiate the development of a master technology to the point of creating new market cycles.

Within a technology-market cycle, there will be a period of variation and refinement of product capabilities, but no major changes in the main uses and customers for the technology. The second research question is:

RQ2: Enabling technologies are more likely to add to the variation and refinement process than to create major new uses and customer segments.

A third possibility is that the enabling technologies individually do not have enough of an influence on industry development to change the industry dynamics or create new ones. It may be that several enabling technologies need to be combined rather than one adopted to develop a new technologymarket cycle. The third research proposition is:

RQ3: Enabling technologies must combine to truly change industry dynamics. 


\section{RESEARCH METHODS}

In this empirical study, we use historiography to review the history of industrial robot development and enabling technologies for the period of the 1940s to 2000s. We base our research on enabling technology development in the industrial robotics industry. Industrial robotics was chosen because they are complex system technologies with several enabling, subordinate technologies. Additionally, this industry is now over 50 years old, providing data on multiple technology-market cycles. We use statistical data from various agencies, such as the International Federation of Robotics, to examine the technology and market evolution trends. The research approach is to use both primary and secondary data to create a history of the industry and to explore the pre and post changes in the industry from the inclusion of an enabling technology. Using the recommendation if Yin (1994), we use in-depth case analysis to inform our research questions. The industry case was deliberately selected and the methodology presented here is consistent with the objectives of qualitative research (Glaser and Strauss, 1965; Marion et al., 2012). The research methodology we followed is related to past qualitative works that include Karjalainen and Snelders (2010), Brockman et al. (2010) and Mabert et al. (1992). Each of these utilize in-depth small sample size case research to drive new theory on technology and product development.

\section{RESULTS AND DISCUSSION}

The first analysis we did was to see if there were changes in the industry dynamics over time. The following tables show that the industry had major shifts in technologies and applications over time. With these shifts, there was entry of new competitors and displacement of existing competitors.

Table 2. Industrial Robot Technology Cycles and Their Market Sizes

\begin{tabular}{|c|c|c|c|c|}
\hline Generation & Characteristics & Main Applications & Major Players & $\begin{array}{l}\text { Market Size } \\
\text { (at mature stage) }\end{array}$ \\
\hline First & $\begin{array}{l}\text { - without or with little } \\
\text { Computer-Controlled Robot } \\
\text { - fixed control programs }\end{array}$ & $\begin{array}{l}\text { Machine loading and } \\
\text { material handling, Spot } \\
\text { welding } \\
\text { and Spray painting }\end{array}$ & $\begin{array}{l}\text { Unimation, AMF Versatran } \\
\text { and Auto Place }\end{array}$ & \$ 418 million \\
\hline Second & $\begin{array}{l}\text { - Computer Controlled Robot } \\
\text { - Adaptive }\end{array}$ & Assembly and Painting & $\begin{array}{l}\text { Unimation, Cincinnati } \\
\text { Milacron, ASEA }\end{array}$ & \$4 Billion \\
\hline Third & $\begin{array}{l}\text { - Multiple Computer Controlled } \\
\text { - more flexible } \\
\text { - advanced version }\end{array}$ & $\begin{array}{l}\text { Handling operation, arc } \\
\text { Welding, Assembly, } \\
\text { Dispensing, Processing }\end{array}$ & $\begin{array}{l}\text { ABB, KUKA, Yaskawa, } \\
\text { FANUC }\end{array}$ & \$29 Billion \\
\hline
\end{tabular}

Source: derived from multiple sources.

As part of the industry dynamics, we determined that there is preliminary evidence of the Balachandra et al. (2004) model being a good representation of the industry dynamics. We found that since the first industrial robot was installed in a General Motors body and assembly plant in New Jersey in 1961 (Westerlund, 2000), the industrial robot industry has gone through three distinct technology generations (Rosen, 1999): the first with little or no computer-control, the second with minicomputer and microcomputer control, and a third with multiple-computer control using rudimentary Artificial Intelligence (AI). From a market perspective, we see two major increases in sales overtime as shown in Figure 2. These correspond with the second and third generation of robots described in Table 2. 


\section{The Shipment of Industrial Robots in the US from 1979-2003 \$ Million}

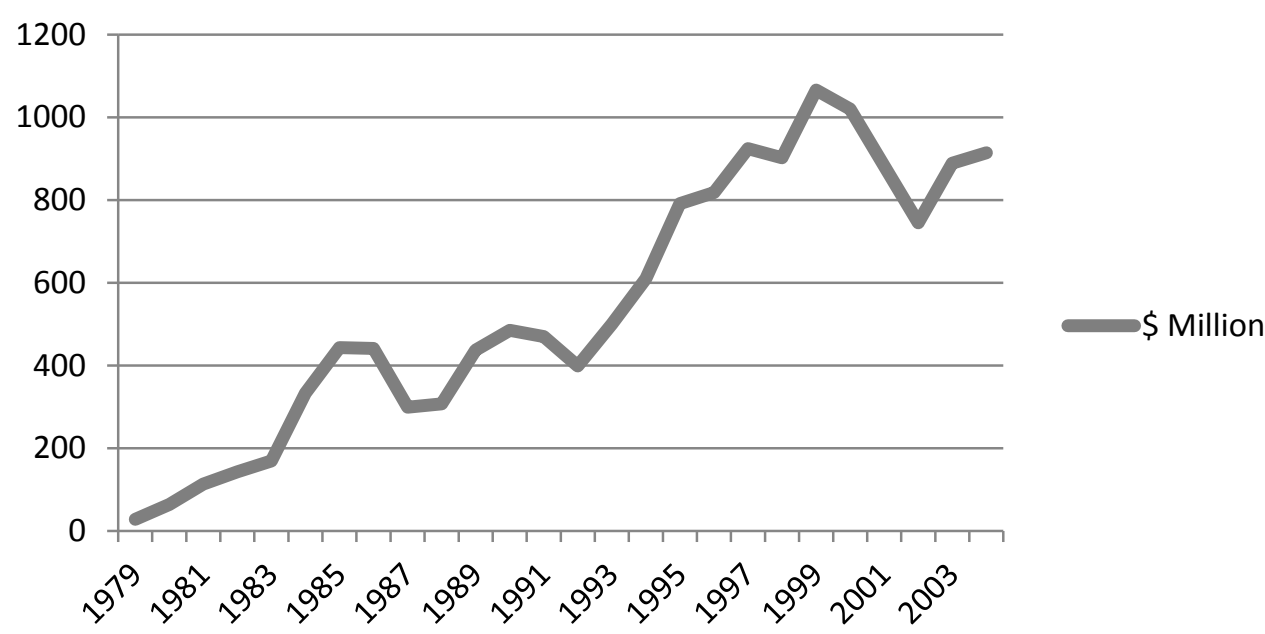

Figure 2. Sales revenue (\$) of industrial robots in the US

Source: United Nations Economics Commission for Europe (UNECE) and International Federations of Robotics (IFR), world robotics 2005.

For each distinct technology cycle, the development of industrial robot technology has gone through several stages, which includes introduction, growth, maturity and decline. Meanwhile, the market side associated with robot technology experienced a similar process.

Table 2. The Market Share of Three Generations of Industrial Robot Technology

\begin{tabular}{|l|c|c|c|c|c|}
\hline \multicolumn{1}{|c|}{$\begin{array}{c}\text { Robotics } \\
\text { Technology } \\
\text { Generation }\end{array}$} & $\mathbf{1 9 7 3}$ & $\mathbf{1 9 8 0}$ & $\mathbf{1 9 8 5}$ & $\mathbf{1 9 9 0}$ & $\mathbf{1 9 9 5}$ \\
\hline $\begin{array}{l}\text { Robot with } \\
\text { little or no } \\
\text { computer- } \\
\text { control }\end{array}$ & $100 \%$ & $70 \%$ & $50 \%$ & $25 \%$ & $\mathrm{n} / \mathrm{a}$ \\
\hline $\begin{array}{l}\text { Robot with } \\
\text { minicomputer } \\
\text { and } \\
\text { microcomputer } \\
\text { control }\end{array}$ & $\mathrm{n} / \mathrm{a}$ & $30 \%$ & $50 \%$ & $75 \%$ & $100 \%$ \\
\hline $\begin{array}{l}\text { Robot with } \\
\text { multiple- } \\
\text { computer } \\
\text { control using } \\
\text { limited }\end{array}$ & $\mathrm{n} / \mathrm{a}$ & $\mathrm{n} / \mathrm{a}$ & $\begin{array}{l}5 \% \text { of robots } \\
\text { have adaptive } \\
\text { control. }\end{array}$ & $\begin{array}{l}25 \% \text { of robots } \\
\text { have vision, } \\
20 \% \text { of robots } \\
\text { have } \\
\text { tactile/touch } \\
\text { sensors. }\end{array}$ & $\begin{array}{l}\text { 96\% of robots } \\
\text { were } \\
\text { "intelligent } \\
\text { universal } \\
\text { programmabl } \\
\text { e" types. }\end{array}$ \\
$\begin{array}{l}\text { Intelligence } \\
\text { AI) }\end{array}$ & & & & & \\
\hline
\end{tabular}

For the first-generation technology, it started with the introduction of the first industrial robot by Unimation, located in the United States. This fairly new technology took more than five years to find its first customer, and then struggled to find others. Following Unimation, other companies entered the industry. They tried different types of applications to fit the market's needs. Many of them failed. One example was the walking industrial robot. Eventually industrial robot producers found a market in Japan in the late 1960s. Although industrial robot technology was very disruptive during 1960s and 1970s, the technology still had limitations, such as it did not have enough memory to store the 
programs carrying the instructions that the robots needed to execute. The market for industrial robots was slow growing, and was mainly limited to the automobile industry in applications such as welding and paint application.

Due to first-generation technology limitations, different companies tried to develop various new technologies. A minicomputer-controlled robot, the T3, was introduced by Cincinnati Milacron Corporation in 1973, and an electronic microprocessor-controlled industrial robot was introduced by Swedish firm ASEA in 1974. By using minicomputers and microcomputers, these two enabling technologies together heralded the start of the second-generation industrial robot technology.

Although second-generation technology was introduced, it was relatively new and needed to take time to find its market. Therefore, it was not until the 1980s, with more companies entering market, that the industrial robot industry experienced rapid growth. Underneath the market expansion, usage of first generation industrial technology reached its maturity and started to decline. By the end of the 1980s, the market share of second-generation technology exceeded the first generation. During the first and second-generation technologies transition period, many firms went out of the market. A large portion of them either were acquired by larger firms or merged with other companies.

With the first generation technology fading and the second generation growing, the third one started. In the 1980s, industrial robot companies started to enhance the accuracy, speed and flexibility of the industrial robots by using early Artificial Intelligence technology, such as machine learning via computer vision, tactile sensors, and motion and manipulation.

Since the 1990s, multiple-computer controlled and AI-based "intelligent" industrial robots have become more popular in order to meet market needs. However, Artificial Intelligence technology was still in the very early stage with many limitations. The second-generation technology still dominated the market.

Given that the history of the industry evinces a coevolution pattern, we set about to determine the main enabling technologies. Enabling technologies were determined by having the most citations as leading technical advances in relevant robotics literature.

Based on our research of history of industrial robots, we developed a preliminary list of enabling technologies, which changed the technology-market cycles of industrial robots. For the first generation, the enabling technologies for first-generation technology included:

1. Servo-mechanism theory

2. Digital computation

3. Solid state electronics

These three technologies were developed during or after the Second World War (Joseph F. Engelberger, 1999). Together, they enabled the industrial robot to go from fantasy to reality with the first applications in the automotive industry.

Enabling technologies for second-generation technology include:

1. Minicomputer technology

2. Microcomputer technology

3. Digital encoders

Minicomputer and microcomputer technologies powered the industrial robots' 'brain.' The larger memory offered more space to store programs, which allowed industrial robots to perform more complicated tasks. The higher computing capability improved the productivity of industrial robots. Digital encoders allowed for accurate placement and coordination of movement, leading to applications such as the manufacture of populated printed circuit boards.

Enabling technologies for third-generation technology include:

1. Early Artificial Intelligence or machine learning

2. Highly controlled motion and manipulation

3. Computer / Machine vision

4. Tactile sensors 
Artificial Intelligence as a modern science was started from the 1950s (Buchanan, 2005). But rudimentary Artificial Intelligence technology by way of machine learning was not commercialized until the 1980s. It increased the accuracy, flexibility and productivity of industrial robots, and enabled industrial robots to be used in more industries. Very early applications included teachable recognition of parts such as resistors or capacitors used in printed circuit board (PCB) manufacture.

During each of the generations, it was the combination of enabling technologies that allowed the creation of the following generation. In our research, we found that there is support for RQ1. Enabling technologies initiate the development of a new technology-market cycle, shown here in this case example through industrial robotic development. We do not find support for RQ2, as many of the enabling technologies allowed for new types of applications. An example is the application of industrial robotics to the placing the electronic components on circuit boards. Driven by better machine vision, sensors, and highly controlled movement, small components could be placed rapidly and accurately - replacing mechanical and human placing of components. Lastly, we find support for RQ3. Enabling technologies do create new technology and market cycles. The recent third generation is in a period of refinement, with continued improvement of intelligence, programmability, and sensors allowing new factory and warehouse floor applications such as package delivery systems at Amazon.

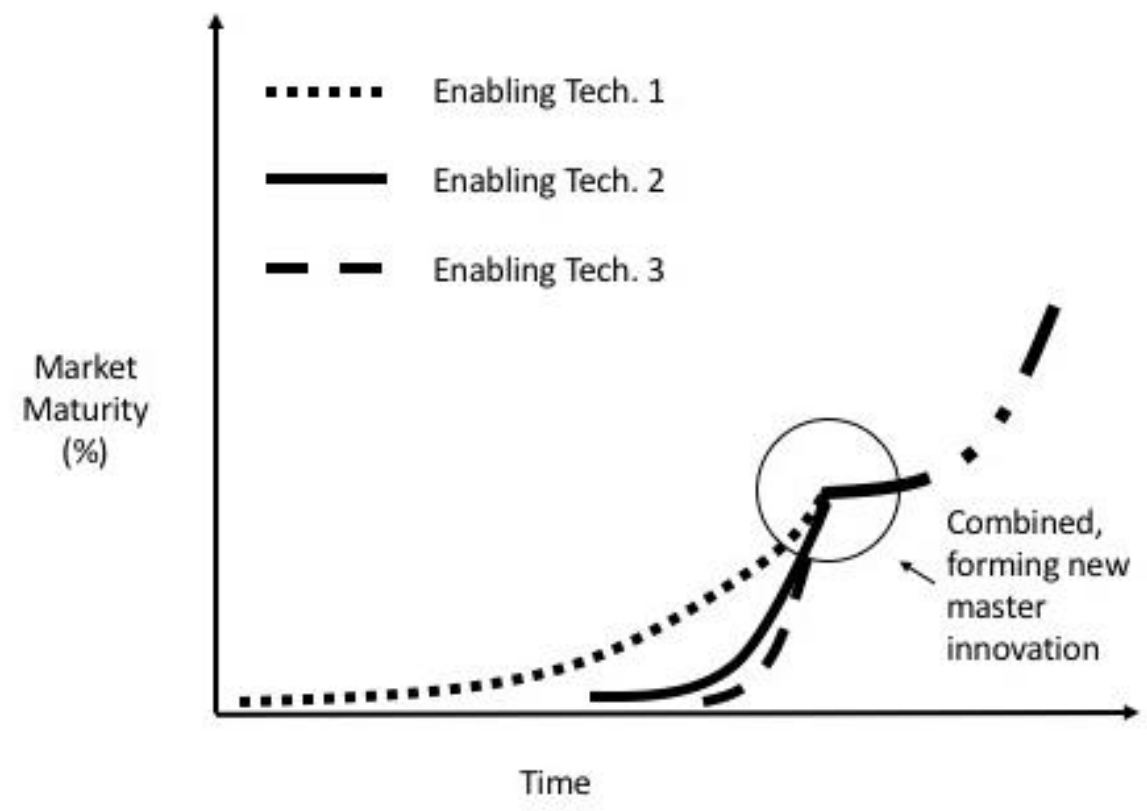

Figure 3. Enabling technology cycle

The combination of enabling technologies, each with their own maturity cycle, is shown in Figure 3. From the industrial robot example, it is only when each of these technologies align and combine, that a new industry cycle can develop. Related, over multiple generations we see that this cycle continues. This is shown in Figure 4 noting two generations of the cycle. This correlates to generation 1 and 2 of industrial robots. 


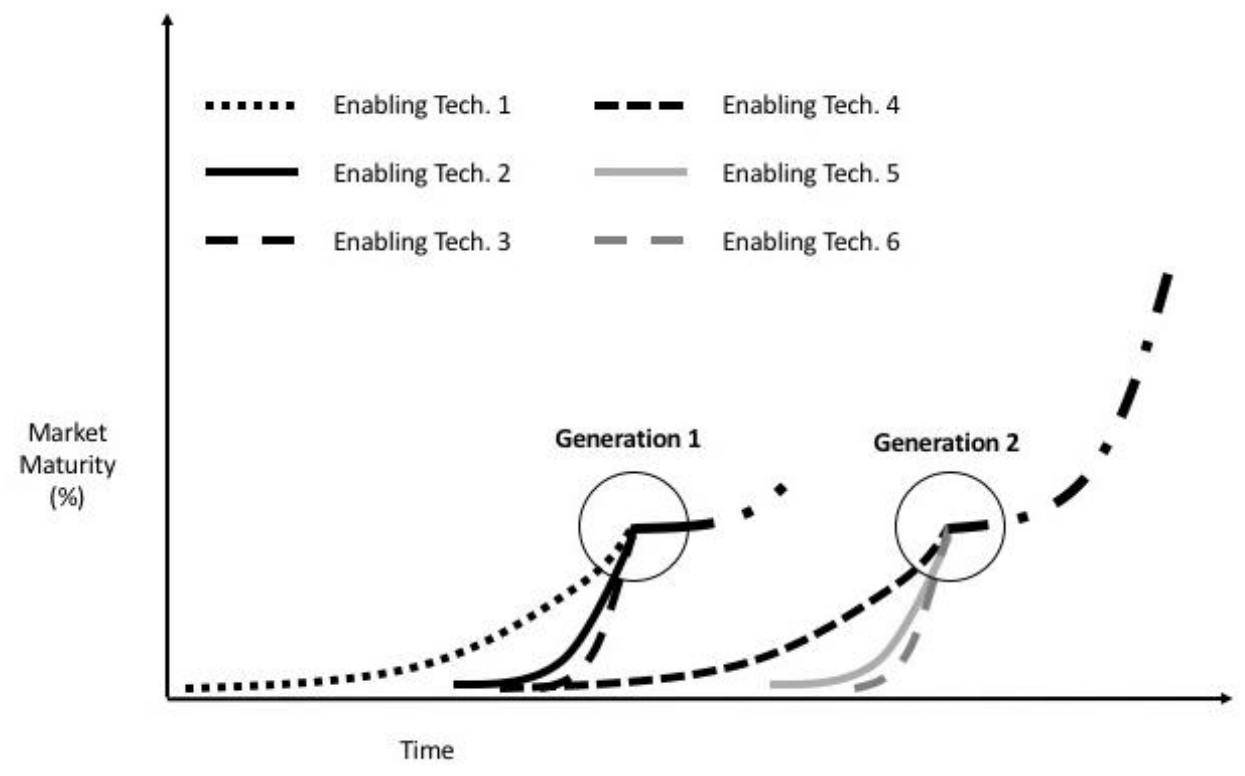

Figure 4. Enabling technology generation cycle

\subsection{Practical implications}

There are several practical implications for executives in technology-based organizations. First, in looking at R\&D for next generation products and systems, engineers and managers need to be familiar with the market-technology cycles for key individual technologies. For example, executives at Telsa understood that low-cost lithium ion batteries were the enabling technology to realize volume electric vehicle production. In order to shift the market-technology curve of this enabling technology, they decided to produce their own batteries in a very high volume manufacturing facility (e.g. the Gigafactory located in Nevada, U.S.). Additionally, for transformative innovations such as extremely fast mass transportation systems, multiple new technologies may need to be created. In planning for this, new types of development methods and organizations may need to be developed, funded, and fostered. We see this currently with the Hyperloop teams. These compete globally, but also share key insights in new technology development. R\&D managers need to be keenly aware of these technologies but also be willing to invest in strategies to change the trajectory of key enabling technologies.

Related is the issue of competitive scanning. Companies using existing enabling technologies may get an incremental improvement by which one might gain some market share. But those using new enabling technology can wipe out the incumbents. How to manage this becomes an issue for both incumbents and new entrants. This impacts not only individual component suppliers, but producers of systems. For system producers, when should you switch to new enabling technologies and how does this fit into product roadmaps becomes a major R\&D decision. Given the long timeframe of complex systems, this is an important process to manage. For example, a large medical systems supplier of ventilators and anesthesia machines is currently evaluating a completely new technology for the sensing of breath and gas flow. A new technology applied in a new form factor, could dramatically improve efficacy of the system, being revolutionary for this particular industry vertical. The executives planning on whether to pursue this need to factor risk and possible delays in development cycles of the enabling technology.

Ultimately, these findings give an indication of where companies should look for market acceptance before and after the incorporation of enabling technologies into their product or system. This raises a series of questions that R\&D executives need to consider. Does the incorporation of enabling technology create a disruption to the market so that a new industry development cycle starts with its concomitant new diffusion cycle; or does the enabling technology create refinement and diversity so that existing industry structures remain intact, but new marketing approaches are required; or is the influence of the enabling technology so weak as to have no impact in changing the trajectory of the industry?

\subsection{Conclusions and limitations}

In this study, we present an in-depth case study detailing a new model for understanding the development of major, transformative innovations. We propose that the key to modeling these major innovations is the mapping and technology-market cycle of individual, enabling technologies. We propose that only when 
these enabling technologies align in their maturity, does this allow a major innovation to occur. This has substantial implications for those firms developing enabling technologies, and for those firms combining them into systems. This study is an in-progress exploratory analysis of enabling technologies' influence on the trajectory of industry development using a co-evolutionary model of development, and as such is limited in its scope and ability to prove the underlying theory. To fully vet this new model, more data and industry investigation needs to be undertaken.

\section{REFERENCES}

Abernathy, W. and Clark, K.B. (1985), "Innovation: Mapping the winds of creative destruction", Research Policy, Vol. 14 No. 1, pp. 3-22.

Abernathy, W.J. and Utterback, J.M. (1978), "Patterns of industrial innovation”, Technology Review, Vol. 80 No. 7, pp. 40-47.

Balachandra, R., Goldschmitt, M. and Friar, J.H. (2004), "The evolution of technology generations and associated markets: A double helix model", IEEE Transactions on Engineering Management, Vol. 51 No. 1, pp. 3-12.

Baltes, H., Brand, O., Fedder, G.K., Hierold, C., Korvink, J.G. and Tabata, O. (Eds.) (2013), Enabling Technology for MEMS and Nanodevices: Advanced Micro and Nanosystems, John Wiley \& Sons.

Brockman, B.K., Rawlston, M.E., Jones, M.A. and Halstead, D. (2010), "An exploratory model of interpersonal cohesiveness in new product development teams", Journal of Product Innovation Management, Vol. 27, pp. 201-219.

Buchanan, B. (2005), “A (very) brief history of artificial intelligence", AI Magazine, 2005

Engelberger, J.F. (1999), "Historical perspective and role in in automation", Handbooks of Industrial Robotics, chapter 1 .

Christensen, C. (2000), M.(1997), The Innovator's Dilemma: When New Technologies Cause Great Firms to Fail, Harvard Business Review Press, Cambridge, MA.

Christensen, C.M., Johnson, C.W. and Horn, M.B. (2010), Disrupting Class. McGraw-Hill.

Dosi, G. (1982), "Technological paradigms and technological trajectories: a suggested interpretation of the determinants and directions of technical change", Research Policy, Vol. 11 No. 3, pp. 147-162.

Gallini, N. and Scotchmer, S. (2002), "Intellectual property: when is it the best incentive system?", Innovation Policy and the Economy, Vol. 2, pp. 51-77.

Glaser, B.G. and Strauss, A.L. (1965), "The discovery of substantive theory: A basic strategy underlying qualitative research," American Behavioral Scientist, Vol. 8 No. 6, pp. 5-12.

Karjalainen, T. M. and Snelders, D. (2010), "Designing visual recognition for the brand", Journal of Product Innovation Management, Vol. 27 No. 1, pp. 6-22.

Kuhn, T. (1962), IX. The Nature and Necessity of Scientific Revolutions.

Loch, C.H. and Huberman, B.A. (1999), "A punctuated-equilibrium model of technology diffusion", Management Science, Vol. 45 No. 2, pp. 160-177.

Mabert, V.A., Muth, J.F. and Schmenner, R.W. (1992), "Collapsing new product development times: Six case studies", Journal of Product Innovation Management, Vol. 9, pp. 200-212.

Marion, T. J., Friar, J. H. and Simpson, T. W. (2012), "New product development practices and early-stage firms: Two in-depth case studies", Journal of Product Innovation Management, Vol. 29 No. 4, pp. 639-654.

Moore, G.A. (1991), Crossing The Chasm, Harper Business, New York.

Murray, F. and O'Mahony, S. (2007), "Exploring the foundations of cumulative innovation: Implications for organization science", Organization Science, Vol. 18 No. 6, pp. 1006-1021.

Rosen, C. (1999), Robots and Machine Intelligence, chapter 3.

Schumpeter, J. (1942), "Creative destruction", Capitalism, Socialism and Democracy, Vol. 825, pp. 82-85.

Schweisfurth, T., Tietze, F. and Herstatt, C. (2011), "Exploring the coevolution of design and technology",

Silverman, D. (2000), Doing Qualitative Research, Sage Publications, London.

Utterback, J. M. and Suárez, F. F. (1993), "Patterns of industrial evolution, dominant designs, and firms' survival",

Stieglitz, N. (2003), "Digital dynamics and types of industry convergence: the evolution of the handheld computers market", The Industrial Dynamics of the New Digital Economy, Vol. 2, pp. 179-208.

Suarez, F. F., Grodal, S. and Gotsopoulos, A. (2015), "Perfect timing? Dominant category, dominant design, and the window of opportunity for firm entry", Strategic Management Journal, Vol. 36 No. 3, pp. 437-448.

Westerlund, L. (2000), The Extended Arm of Man: A History of the Industrial Robot Informationsforlagest, Stockholm, Sweden.

Yin, R.K. (1994), Case Study Research: Design and Methods, Sage Publications, Thousand Oaks, CA.

\section{ACKNOWLEDGMENTS}

We would like to thank research assistant Amy Ma for her assistance in compiling this research. 